\title{
CRITERIA OF EFFECTIVENESS OF STUDENTS' PHYSICAL EDUCATION SYSTEM IN HIGHER EDUCATIONAL ESTABLISHMENTS
}

Anikieiev D.M.

Institute of Penal Service

\begin{abstract}
Purpose: to work out criteria, permitting assessment of physical education in higher educational establishments. Material: theoretical analysis and generalization of scientific methodic literature and documents; method of experts' assessments. As experts, 26 professors and associate Professors of higher educational establishments of different profile were invited (13 doctors of science and 13 candidates of science). Results: we have generalized the data about effectiveness criteria of physical education, present in program normative documents. We have presented criteria, permitting to quantitatively assess the correspondence of physical education, in higher educational establishments, results to its purposes and tasks. Conclusions: the most acceptable method of physical education quality control is regular monitoring of indicators of students' physical condition. Individual target of every student shall be indicators of academic trainings' quality. Analysis of optional lessons' attendance is also very important indicators of quality of students' physical condition.
\end{abstract}

Key words: physical, fitness, health, expertise, optional, student.

\section{Introduction}

In the most general case effectiveness is the level of correspondence of any functioning results to the set task. Risk is a possibility of failure in this functioning [1]. Criterion (from Greek kriterion - mean for judgment) - is a sign, on the base of which assessment, determination and classification of something; measure of assessment [4]. Thus, criteria of effectiveness of physical education are understood by us as measures of correspondence of physical education results to the set tasks.

In Article 26 of Law of Ukraine "On physical culture and sports" (adopted in 2009) it is noted: "physical culture in educational sphere shall be targeted at ensuring students and pupils' physical health, complex approach to formation of mental and physical abilities of a personality, perfection of physical and psychological fitness for active life, professional functioning on the base of individual approach, priority of health related orientations, wide usage of different forms and means of physical education and mass sports, continuous character of this process during all life" [10].

Academic program for Ukrainian higher educational establishments of $3^{\text {rd }}-4^{\text {th }}$ levels of accreditation [14] defines nine criteria of effectiveness of graduate's physical education and not all of them can be put in the base of exact control methods and assessment of physical education quality. As on to-day there are no clearly determined effectiveness criteria for physical education in higher educational establishments. Decree of the Cabinet of Ministers, dt. November 5, 2008, №992 cancelled tests for assessment of population’s physical fitness. Time and practice show that with positive character of intentions, State system of tests was not perfect. For example, Yu. Vykhliayev et al. [5] think that except actually important motor qualities of such tests (for example, endurance and strength) they also include not very important for human life qualities (jumping ability, quickness, dexterity, flexibility and swimming). It makes the system bulky and devaluates importance of first two qualities - endurance and strength. So the authors developed alternative methodic of assessment of physical condition.

The use of its application is confirmed by V. Samoshkin13], who determined satisfactory correlation coefficients (from 0.27 to 0.63 ) between level of cardio-respiratory system's functional potentials and students' physical fitness. The author confirmed existence of direct connection between health condition and physical fitness. From point of view of V. Samoshkin [13], it is also important to consider student's motor regiment.

The system of tests and normative shall strictly correspond to targets, tasks and content of physical education. It shall meet age and gender peculiarities of people, health condition. The system shall not require extreme physical loads. A.T. Litvin offer base (in assessment of physical education effectiveness) on criteria, grouped in six blocks: body constitution, condition of most important functional systems, weekly volume of energy consumption due to motor functioning, weekly scope and correlation of different kinds of motor functioning, indicators of strength, coordination and flexibility; morbidity [12].

Alongside with it, variety of opinions in respect to criteria of physical education effectiveness requires to conduct additional researches and analyze existing publications. 
Purpose, tasks of the work, material and methods

The purpose of the research is to work out criteria, permitting assessment of physical education in higher educational establishments.

We used the following methods of the research in compliance with tasks and purpose of our work: theoretical analysis and generalization of scientific-research literature and documents, method of experts' assessments. Analysis of official documents was fulfilled by methodic, which is sufficiently completely described inA special literature $[6,7]$. In the research we used the following kinds of experts' assessments: method of preference and method of direct assessment [7].

As experts, 26 professors and associate Professors of higher educational establishments of different profile were invited (13 doctors of science and 13 candidates of science).

\section{Results}

Analysis of physical education and sports in Ukrainian higher educational establishments showed that just higher school is the last stage of future specialists' training for independent activity. It imposes great responsibility for students' health and physical fitness on pedagogic staff [8].

In official documents, regulating students' physical education there is no clear formulation of its tasks and aims. That is why for determination of priorities in physical education in HEEs experts were given the task: "Rank the tasks to be solved by physical education in HEE by their importance". Results of expertise by method of preference (after reducing quantity of experts by Delfa's method) are given in table 1 .

Table 1. Results of experts' questioning about importance of tasks to be solved by HEE physical education ( $\mathrm{W}=$ $0,82, \mathrm{n}=21)$

Object of expertise: ranking of tasks to be solved by HEE physical education

Formation of motivation - value attitude to physical culture, demand in regular practicing of physical exercises and sports

Formation of system of knowledge about physical culture and healthy life style

Strengthening of health, promoting of correct formation and comprehensive development of organism prophylaxis of diseases, ensuring of high physical condition, workability for all period of studying

Acquiring of motor skills' fund, general and professionally-applied physical fitness

Preparation for State or departmental tests and normative of physical fitness at level of requirements of educational-qualification characteristics and educational-professional programs for certain specialists

One of the most important problems of construction of HEE physical education technology is to form student's interested attitude to discipline, to awaken interest to building healthy body, to form own health in the widest sense [3]. Only if a student understands real possibility of such influence on own organism it becomes possible to effectively solve separate motor tasks, which are the components of every academic training [9].

That is why one of questionnaire's items implied definition of the most acceptable methods of physical education quality control in HEE. Results are given in table 2.

Table 2. Results of experts' questioning about the most acceptable methods of physical education quality control in HEE $(W=0,789, n=24)$

\begin{tabular}{lc}
\hline Object of expertise: the most acceptable method of physical education quality control in HEE. & Rank \\
\hline Testing of physical fitness & 2 \\
Regular monitoring of physical condition indicators, changes of which is individual target of a student & 1 \\
Analysis of optional trainings' attendance on senior years of studying (after finishing of compulsory & 3 \\
trainings) & 4 \\
Monitoring of theoretical knowledge on physical culture and healthy life style & 5 \\
Other methods & \\
\hline
\end{tabular}


Considering modern students' low motivation for practicing physical exercises we organized experts' assessment of methods of students' motivation for physical culture. The results are given in table 3.

Table 3. Results of experts' questioning about methods of students' motivation for physical culture $(W=0,738$, $\mathrm{n}=23$ )

\begin{tabular}{lc}
\hline \multicolumn{1}{c}{ Object of expertise: methods of students' motivation for physical culture } & Rank \\
\hline Semester physical education test & 2 \\
Current physical education testing & 3 \\
Regular monitoring of physical condition indicators, changes of which is individual target of a student & 1 \\
Every year State testing of physical fitness & 4 \\
Other methods & 5 \\
\hline
\end{tabular}

Thus, regular monitoring of physical condition indicators (as individual target of a student) is, at the same time, the most acceptable methods of physical education quality control and motivation of students for trainings. Just achievement of individual target is a powerful factor, stimulating further activity. Any activity is regulated and controlled owing to feedback. If results grow, motivation for activity increases. That is why testing of results creates strong positive emotional feeling and gives new impulse for self-perfection $[11,15]$. Though, choice of physical condition indicators to be improved in physical education process - is an open question. With it, it is necessary to base on our questioning of students [2]. Physical condition indicators can be divided into 2 groups:

1. Indicators, connected with good appearance (fat percentage, correlation of muscular and fat tissues and so on);

2. Indicators, connected with strengthening of health (functional indicators of cardio-respiratory systems, muscular skeletal apparatus and etc.).

It should also be noted that it is important to correctly choose physical condition indicators. Positive changes of these indicators will facilitate solution the main task in HEEs: formation of students' motivation-value attitude to physical culture, demand in regular practicing of physical exercises and sports.

\section{Discussion}

Results of our researches confirmed the data of other authors about importance of physical education quality control and correct choice of physical condition indicators of students [16-20, 23-26].

When composing academic plan on physical education it is necessary to consider that physical fitness and health can not be preserved for future usage. Regular motor functioning is important target for students. Students shall feel advantages of healthy life style already in the process of studying. After graduation advantages, acquired with physical exercises, will quickly disappear. Thus, academic plan shall form students' responsibility for their way of life [21, 22].

Unfortunately, nowadays there appears danger tendency to refuse compulsory physical education lessons in HEEs for saving money, required for maintenance of sport facilities. These actions are provoked by the following:

- Order of Ministry of education and science, dt. January 26, 2015, № 47 “On formation of curriculums for 2015/2016 academic year";

- Letter of MES of Ukraine, dt. 13.03.2015 № 1/9-126.

In this letter it is noted: "Physical culture trainings in sport circles can be organized both as optional (i.e. they are not included in curriculums and have no final control)". It contradicts to Cl.26, it. 4 and it. 17 of Law of Ukraine "On higher education". In these documents it is noted: "Administrators of higher educational establishments are obliged to create favorable conditions for proper motor functioning of students".

That is why analysis of optional trainings' attendance we consider to be very important indicator of physical education quality at HEEs in spite of the fact that it takes only third position be results of expertise. Its correspondence to the task, which id the most important in HEEs: formation of motivation-value attitude to physical culture, demand in regular sports' and physical exercises' practicing, attracts attention. Optional trainings can be paid but in reasonable limits. A share of the earned money can be directed for financial incentives of instructors.

\section{Conclusions}

The most acceptable method of physical education quality control in HEEs is regular monitoring of students' physical condition indicators. Indicators of trainings' quality shall be individual target of every student. Alongside with it, analysis of optional trainings' attendance we consider to be an important indicators of physical education quality at HEE. 


\section{Acknowledgement}

The problem of the work corresponds to topic 3.1 "Perfection of program-normative principles of physical education in educational establishments" of combine plan of SRW in sphere of physical culture and sports for 2011-2015.

\section{Conflict of interests}

The author declares that there is no conflict of interests.

\section{References:}

1. Alekseev VV. Razrabotka logiko-veroiatnostnykh modelej, metodov i algoritmov dlia upravleniia riskom $i$ effektivnost'iu v strukturno-slozhnykh sistemakh. Cand. Diss. [Development of logical-probabilistic models for control of risks and effectiveness in structurally-complex systems. Cand. Diss.]. Sankt Petersburg; 2009. (in Russian)

2. Anikieiev DM. Analiz sposobu zhittia suchasnoi students'koi molodi [Analysis of modern students' life style]. Moloda sportivna nauka Ukraini. 2010;2:10-14. (in Ukrainian)

3. Antonova TV. Pedagogicheskie usloviia valeologicheskogo samorazvitiia studenta v processe fizicheskogo vospitaniia. Cand. Diss. [Pedagogic conditions of student's valuelogic self-development in physical education process. Cand. Diss.]. Cheboksary; 2005. (in Russian)

4. Bol'shoj Enciklopedicheskij Slovar' [Large Encyclopedic Dictionary]. Available at: http://slovari.299.ru/enc.php (accessed 23.07.2015)

5. Vikhliaiev Iu, Sichov S, Shcherbachenko V. Ocinka fizichnoi pidgotovlenosti studentiv [Assessment of students' physical fitness]. Vseukrains'ka naukova praktichna konferenciia, Kiiv, 1988. "Students'kij fizkul'turno-sportivnij rukh v Ukraini na porozi XXI stolittia” Kiiv, 1998. [All-Ukrainian scientific-practical conference, Kyiv, 1988. "Students' physical culture - sports movement in Ukraine on the eve of 21 st century", Kyiv, 1988]. Kiev; 1998. p. 111. (in Ukrainian)

6. Godik MA. Sportivnaia metrologiia [Sport metrology]. Moscow: Physical Culture and Sport; 1988. (in Russian)

7. Denisova LV. Izmereniia i metody matematicheskoj statistiki v fizicheskom vospitanii i sporte [Measurements and methods of mathematical statistic in physical education and sports]. Kiev: Olympic Literature; 2008. (in Russian)

8. Dolzhenko LP. Fizicheskaia podgotovlennost' i funkcional'nye osobennosti studentov s razlichnym urovnem fizicheskogo zdorov'ia. Cand. Diss. [Physical fitness and functional characteristics of students with different level of health. Cand. Diss.]. Kiev; 2006. (in Russian)

9. Durkin PK, Lebedeva MP. K probleme vospitaniia lichnoj fizicheskoj kul'tury u shkol'nikov i studentov [On the problem of cultivation of pupils' and students' personal physical culture]. Fizicheskaia kul'tura: vospitanie, obrazovanie, trenirovka. 2000;2:50-53. (in Russian)

10. Zakon Ukraini "Pro fizichnu kul'turu i sport" [Law of Ukraine: "On physical culture and sports"] Oficijnij visnik Ukraini, 2009;97:30 (in Ukrainian)

11. Korolins'ka SV. Klubna forma organizacii fizichnogo vikhovannia u vishchikh navchal'nikh zakladakh. Cand. Diss. [Cub form of physical education organization in higher educational establishments. Cand. Diss.]. Lviv; 2007. (in Ukrainian)

12. Litvin AT. Istoricheskie predposylki i teoretiko-metodologicheskie osnovy sovremennoj sistemy fizicheskogo vospitaniia. Cand. Diss. [Historical pre-conditions and theoretical-methodological principles of modern system of physical education. Cand. Diss.], Kiev, 2007. (in Russian)

13. Samoshkin VV. Vzaiemozv'iazok funkcional'nogo rezervu kardiorespiratornoi sistemi ta fizichnoi pidgotovlenosti studentiv [Interconnection of cardio-respiratory systems' functional reserve and students' physical fitness]. Vseukrains'ka naukova praktichna konferenciia "Aktual'ni problemi fizichnogo vikhovannia u vuzi”, Donec'k. 1998 [All-Ukrainian scientific-practical conference "Actual problems of physical education in HEE, Donetsk, 1998.]. Donetsk; 1998. (in Ukrainian)

14. Fizichne vikhovannia, navchal'na programa dlia vishchikh navchal'nikh zakladiv Ukraini 3-4 rivniv akreditacii [Physical education, academic program for higher educational establishments of Ukraine of 3rd4th accreditation levels]. Kiev; 2003. (in Ukrainian)

15. Forrester S. Student attitude toward sports and fitness activities after graduation. Scott Forrester, Christopher Arterberry, Bob Barcelona. Recreational Sports Journal, 2006;30:87-99.

16. Iermakova TS. Education of children in Polish family in a context of forming health culture. Pedagogics, psychology, medical-biological problems of physical training and sports, 2014;11:17-22. http://dx.doi.org/10.15561/18189172.2014.1104

17. Iermakova TS. The peculiarities of work of the european network of health promoting schools (comparative analysis). Pedagogics, psychology, medical-biological problems of physical training and sports, 2013;10:9396. http://dx.doi.org/10.6084/m9.figshare.775339 
18. Kolokoltsev MM, Cieslicka Miroslawa, Muszkieta Radoslaw. Optimization of physical training of students of high school with regard to quantitative features muscular components of their bodies. Physical Education of Students. 2015;1:22-30. http://dx.doi.org/10.15561/20755279.2015.0104

19. Kozina ZL, Iermakov SS. Analysis of students' nervous system's typological properties, in aspect of response to extreme situation, with the help of multi-dimensional analysis. Physical Education of Students. 2015;3:1019. http://dx.doi.org/10.15561/20755279.2015.0302

20. Michael Chia, Marcus Lee. Relationship between quality of life and resilience among sport-active Singaporean youth. Physical Education of Students. 2015;2:29-36. http://dx.doi.org/10.15561/20755279.2015.0205

21. PE4life: developing and promoting quality physical education. Champaign: Human Kinetics, 2007;XXIV.

22. Physical Education for Lifelong Fitness: the Physical Best Teacher's Guide. Champaign: Human Kinetics; 1999.

23. Prosvirina LN, Kolokoltsev MM, Kolchanova MA, Cieslicka Miroslawa, Stankiewicz Blazej. The characteristic of the engine qualities of the students of technical institute of III functional health group (special medical group). Physical Education of Students. 2015;1:43-49. http://dx.doi.org/10.15561/20755279.2015.0107

24. Rovnaya OA, Podrigalo LV, Iermakov SS, Prusik Krzysztof, Cieślicka Mirosława. Morphological and functional features of synchronous swimming sportswomen of high qualification. Pedagogics, psychology, medical-biological problems of physical training and sports, 2014;4:45-49. http://dx.doi.org/10.6084/m9.figshare.951916

25. Żukowska Hanna, Szark-Eckardt Mirosława, Muszkieta Radosław, Iermakova TS. Characteristics of body posture in the sagittal plane and fitness of first-form pupils from rural areas. Pedagogics, psychology, medicalbiological problems of physical training and sports, 2014;7:50-60. http://dx.doi.org/10.6084/m9.figshare.1015583

26. Yermakova TS. Individualization of forming health culture in schoolchildren of Polish schools. Pedagogics, psychology, medical-biological problems of physical training and sports. 2015;1:29-33. http://dx.doi.org/10.15561/18189172.2015.0106 


\section{Information about the author:}

Anikieiev D.M.; http://orcid.org/0000-0001-8931-2067;

dmytroanikeev@gmail.com; Institute of Penal Service; st. Manifold, 4, Kyiv, 02121, Ukraine.

Cite this article as: Anikieiev D.M. Criteria of effectiveness of students' physical education system in higher educational establishments. Physical education of students, 2015;5:3-8. http://dx.doi.org/10.15561/20755279.2015.0501

The electronic version of this article is the complete one and can be found online at: http://www.sportpedu.org.ua/html/arhive-e.html

This is an Open Access article distributed under the terms of the Creative Commons Attribution License, which permits unrestricted use, distribution, and reproduction in any medium, provided the original work is properly cited (http://creativecommons.org/licenses/by/4.0/deed.en).

Received: 16.08.2015

Accepted: 29.08.2015; Published: 02.09.2015 